\title{
Sprawozdanie z konferencji „Mother of Exiles”. Amerykańskie wzorce polityki imigracyjnej a wyzwania współczesnej Europy
}

Dnia 24 marca 2018 w Muzeum Emigracji w Gdyni odbyła się konferencja pt. Mother of Exiles. Amerykańskie wzorce polityki imigracyjnej a wyzwania współczesnej Europy, zorganizowana przez Stowarzyszenie Klub Absolwentów Fundacji Kościuszkowskiej przy wsparciu Muzeum Emigracji w Gdyni oraz Instytutu Historii z Wydziału Historycznego Uniwersytetu Gdańskiego. Partnerami przedsięwzięcia były: Fundacja Kościuszkowska oraz Polish-American Historical Association. W wydarzeniu uczestniczyli stypendyści, założonej w $1925 \mathrm{roku}$, Fundacji Kościuszkowskiej, która promuje relacje polsko-amerykańskie wspierając wymianę edukacyjną, naukową i kulturalną. Fundacja rocznie nagradza stypendiami studentów, doktorantów, naukowców, artystów oraz absolwentów, promując polską kulturę w Ameryce.

Celem spotkania była dyskusja naukowa na temat współczesnych migracji oraz stworzenie sprzyjających warunków do nawiązania współpracy i wymiany naukowej między absolwentami Fundacji Kościuszkowskiej. Wagę wydarzenia docenił Zastępca Szefa Misji w Ambasadzie USA w Polsce - John Law, który wygłosił w Gdyni przemówienie na temat amerykańskiej tożsamości kulturowej i roli imigracji w historii Stanów Zjednoczonych.

W konferencji wzięło udział niemal 40 polskich naukowców z różnych ośrodków w kraju. Wśród organizatorów spotkania należy wymienić przede wszystkim

${ }^{1}$ Kontakt: p.napierala@uj.edu.pl 
dr. hab. Roberta Kulskiego, prezesa Stowarzyszenia Klubu Absolwentów. Pośród uczestników spotkania i gości znaleźli się między innymi: Marek Skulimowski prezes Fundacji Kościuszkowskiej, członkinie Rady Fundacji - prof. Ewa Radwańska i dr Hanna Chroboczek-Kelker, a także dr hab. Anna Mazurkiewicz, reprezentująca Polish-American Historical Association oraz Instytut Historii Uniwersytetu Gdańskiego.

Zebranych powitał, w imieniu dyrektor Karoliny Grabowicz-Matyjas, dr Rafał Raczyński, główny specjalista ds. badawczych Muzeum Emigracji w Gdyni, który podkreślił rolę migracji w historii Polski. Następnie głos zabrał dr hab. Robert Kulski, który podziękował dyrekcji muzeum, a także Wydziałowi Historycznemu UG za współpracę przy organizacji konferencji i powitał wszystkich stypendystów. Zaznaczył, że stowarzyszenie powstało pięć lat temu w Warszawie, by propagować misję Fundacji Kościuszkowskiej oraz wspomagać integrację jej stypendystów, przede wszystkim poprzez organizację konferencji, seminariów i wykładów. Podkreślił też, że choć jest ono organizacją młodą, to ma już na swoim koncie pięć wydarzeń naukowych. Pierwszym z nich była konferencja, która odbyła się w Łodzi na Wydziale Prawa i Administracji UŁ, a następnie zorganizowano trzy kolejne takie spotkania na Wydziale „Artes Liberales” Uniwersytetu Warszawskiego. Konferencja w Gdyni jest piątym wydarzeniem naukowym stowarzyszenia, a jej temat został wybrany nieprzypadkowo. Organizatorzy uznali bowiem, że współczesne wydarzenia międzynarodowe, zwłaszcza „kryzys migracyjny” skłaniają do refleksji, a amerykańskie doświadczenia imigracyjne mogą okazać się cenne również w kontekście europejskim.

Następnie gości powitał Prezes Fundacji Kościuszkowskiej, Marek Skulimowski, który podziękował organizatorom za zaproszenie i podkreślił, że Fundacji zależy, by jej działalność była rozpoznawalna nie tylko w Nowym Jorku, ale również w Polsce. Zaznaczył też rolę Grażyny Czetwertyńskiej w propagowaniu działalności Fundacji w kraju, a także przedstawił propozycję, by każde kolejne spotkanie Stowarzyszenia odbywało się $\mathrm{w}$ innym ośrodku naukowym w Polsce.

Po oficjalnych powitaniach nadszedł czas na wystąpienie Zastępcy Szefa Misji w Ambasadzie USA - Johna Lawa. Rozpoczynając swą mowę, zwrócił on uwagę na obchodzoną obecnie 100. rocznicę odzyskania przez Polskę niepodległości oraz podkreślił znaczenie stuletnich stosunków dyplomatycznych między Polską i Stanami Zjednoczonymi. Docenił również wysiłki Fundacji Kościuszkowskiej związane z zacieśnianiem więzi między Stanami Zjednoczonymi a Polską i zachęcił absolwentów do kontynuowania tych starań, zapewniając, że Stany Zjednoczone chcą wspierać polskich badaczy. W dalszej części wystąpienia mówił o znaczeniu imigracji w historii USA oraz procesie tworzenia i określania amerykańskiej narodowej i kulturowej tożsamości. Podkreślił, że Amerykanie nie są narodem posiadającym wspólne korzenie etniczne, co sprawia, że proces ten jest skomplikowany. Przytoczył też kontrowersyjną tezę Samuela Huntingtona, rozdzielającą 
kategorie osadników i imigrantów, zaznaczając przy tym szczególną rolę pierwszych anglosaskich osadników i ich wpływ na stworzone w Ameryce struktury i przyjęte wartości. Następnie omówił dzieje imigracji do USA oraz regulacje, które wprowadzano na różnych etapach historii. Docenił wkład imigrantów w rozwój gospodarczy kraju i omówił procesy wiodące do ich integracji ze społeczeństwem (w tym rolę sportu dla dzieci imigrantów). Na koniec podkreślił, że tożsamość amerykańska nie jest stała i niezmienna, że nie jest ona oparta na więzach krwi, etniczności czy religii, lecz raczej na ideach, które każdy może wyznawać. I choć, jak stwierdził, może być pełna sprzeczności, podziałów i konfliktów, to jednak dzięki temu nieustannie ewoluuje i jest „ideą żywą”.

Po wystąpieniu Johna Lawa, uczestnicy konferencji mieli okazję do zadawania pytań, wśród których nie zabrakło tych dotyczących zniesienia wiz dla Polaków. Po serii pytań i ożywionej dyskusji rozpoczęła się pierwsza naukowa sesja konferencji. Moderował ją dr Rafał Raczyński, a referaty zaprezentowali dr hab. Anna Mazurkiewicz oraz dr hab. Witold Klaus.

Pierwsze wystąpienie dotyczyło historycznych uwarunkowań amerykańskiej polityki wobec uchodźców. Prelegentka rozpoczęła je od refleksji na temat historii USA, którą określiła jako historię równych szans, ale również historię wykluczenia i odrzucenia. Podkreśliła, że przez 150 lat w prawie amerykańskim nie istniało rozróżnienie na migrantów i uchodźców. W tym kontekście, przypomniała o nieprzyjęciu przez USA żydowskich uciekinierów z Europy, przybyłych do wybrzeży Ameryki w 1939 roku na statku St. Louis, zaznaczając jednak, że po upadku Francji, Amerykanie przyjęli ostatecznie około 1200 intelektualistów z Niemiec. Omówiła również wprowadzane $\mathrm{z}$ czasem przepisy i rozporządzenia, $\mathrm{m}$.in. wydaną $\mathrm{w}$ grudniu 1945 roku prezydencką dyrektywę, zgodnie z którą osoby przyjmowane do USA nie mogły być obciążeniem dla budżetu i musiały wykazać się moralnością i „przydatnością”. Wyjaśniła, na jakich zasadach po drugiej wojnie przybywali do Stanów Zjednoczonych DP-si, a następnie przedstawiła dokładnie historię tworzenia amerykańskiego prawodawstwa, odnoszącego się do przyjmowania uchodźców. Wiele uwagi poświęciła aktom prawnym tworzonym w kontekście zimnej wojny. Omówiła m.in. McCarrran-Walter Act czy Refugee Relief Act of 1953, podkreślając, że w tym okresie polityka uchodźcza była bardzo mocno powiązana z celami propagandowymi. Wspieranie i przyjmowanie uchodźców zza „żelaznej kurtyny” pozwalało bowiem wykazać, że uciekają oni „ze zła do epicentrum dobra”. Następnie prelegentka poruszyła problem uchodźców z Kuby, zwanych „boatpeople” (choć nazwa ta była też kojarzona $\mathrm{z}$ chińskimi uchodźcami z Wietnamu). Zaznaczyła również, że przybyszom z Ameryki Łacińskiej status uchodźców przyznawano rzadziej, gdyż Stany Zjednoczone często wspierały panujące tam reżimy. Przechodząc do kolejnego zagadnienia, dodała, że według statystyk społeczeństwo amerykańskie było raczej nieprzychylne przyjmowaniu uchodźców. W praktyce jednak Amerykanie zawsze uzależniali poparcie dla wszelkich kategorii przybyszów od 
ich akceptacji amerykańskich wartości. Dlatego często większe poparcie niż dla uchodźców wyrażali raczej dla imigrantów ekonomicznych, postrzeganych jako osoby, które przybyły do Stanów Zjednoczonych ze względu na panujący tam system ekonomiczny oraz chęć podporządkowania się jego zasadom i innym amerykańskim wartościom. W mniemaniu opinii publicznej, w przypadku uchodźców istniało natomiast niebezpieczeństwo, że pozostaną wierni wartościom i kulturze kraju pochodzenia, traktując pobyć w USA jako przejściowy. Jest to niezwykle ciekawa obserwacja, uwypuklająca pewne paradoksy, zwłaszcza w kontekście obecnego „kryzysu migracyjnego”. Prelegentka zakończyła wystąpienie podkreślając, że amerykańska polityka uchodźcza była wypadkową wielu czynników, w tym: moralnych zobowiązań, politycznych potrzeb (wewnętrznych i zewnętrznych), celów propagandowych, elementów humanitarnych oraz czynników ekonomicznych.

Dr hab. Witold Klaus, reprezentujący PAN oraz UW, wygłosił z kolei referat na temat prawnych kontekstów współczesnych migracji w USA i w Europie. Mówił, że tym, co łączy Stany Zjednoczone i kraje europejskie jest fakt, iż reprezentują one region globalnej Północy, a przybywający do nich migranci są kategoryzowani na różne sposoby. Wyróżnił kilka takich kategorii, np. kategorię osób podróżujących „W dobrej wierze" (bona fide travellers) oraz tak zwanych crimimigrants (w społecznej percepcji łączonych z przestępczością). Zasugerował też, że kategoryzowanie migrantów można symbolicznie przedstawić za pomocą cytatu: „The good, the bad, and the ugly". Wśród pierwszej kategorii będą bona fide travellers, czyli osoby podróżujące legalnie jako stypendyści lub pracownicy wykwalifikowani. Wśród drugiej będą migranci poszukujący pracy, którzy są ekonomicznie potrzebni, ale gdy tylko społeczeństwa przyjmujące przestają ich potrzebować, robią wszystko, by się ich pozbyć. W kategorii the ugly $\mathrm{z}$ kolei znajdą się uchodźcy i osoby nieudokumentowane, których wiele państw stara się nie przyjmować ze względu na ekonomiczne i prawne komplikacje. Pochodzą oni często z tak zwanych państw wykolejonych (deviant states) i często traktowani są jako globalna podklasa. Jak podkreślił prelegent, wobec tych osób prawo stosowane jest bardzo wybiórczo w zależności od tego, czy są one „politycznie wygodne”, czy też nie. Następnie przeszedł do wątku ograniczania prawa do swobodnej migracji w kontekście ochrony bezpieczeństwa. Przypomniał, że w Europie kwestie bezpieczeństwa zostały wprowadzone do prawa wspólnotowego w latach 90. XX wieku, a Polska musiała się do nich zastosować w 2004 roku (wprowadzając m.in. wizy dla Ukraińców). W USA z kolei coraz większą uwagę na ograniczenie prawa do migracji, ze względu na bezpieczeństwo, zaczęto zwracać po atakach z 11 września 2001. W kolejnej części referatu zaprezentował więc sposoby ograniczania swobody migracji, $\mathrm{w}$ tym: wprowadzanie restrykcyjnego prawa (np. utrudniającego wjazd do UE osobom pochodzącym z krajów spoza wspólnoty), tworzenie fizycznych przeszkód (np. zamykanie granic, mury itd.), rozrost granic (tworzenie państw „buforowych”, np. obrona granicy USA już na linii Meksyk-Gwatemala, a granicy UE w krajach 
Afryki Północnej czy Turcji), zwiększanie nadzoru nad migrantami (założenie, że każdy cudzoziemiec stanowi potencjalne zagrożenie i może być inwigilowany), stosowanie detencji (tworzenie placówek przypominających więzienia). Prelegent zaznaczył, że w ostatnim przypadku izolacja migrantów następuje często, mimo że nie popełnili przestępstwa, a jedynie przekroczyli granicę i starają się o status uchodźcy. Co prawda, niekiedy nie posiadają oni dokumentów, nie oznacza to jednak, że powinni być traktowani jak niebezpieczni przestępcy. Tymczasem ośrodki strzeżone w Polsce, w których są przez to osadzani, w wielu przypadkach wyglądają gorzej niż więzienia. Podkreślił też, że ograniczanie praw podstawowych ze względu na bezpieczeństwo często pociąga za sobą dehumanizację jednostek w procedurach prawnych, pozbawienie prawa do ochrony sądowej czy deportację. W tym kontekście prof. Klaus poruszył problem deportacji z USA dzieci migrantów meksykańskich, które nie mają nic wspólnego z tzw. „krajem pochodzenia”, a także zagadnienie „kryminalizacji solidarności”, czyli karania aktywistów i organizacji niosących pomoc migrantom.

Po prezentacjach, w czasie panelu dyskusyjnego, poruszono wiele tematów, m.in.: kwestię ośrodków dla uchodźców w Polsce, dylemat 'bezpieczeństwo versus wolność, zagadnienie migrant trafficking, problem korytarzy humanitarnych czy funkcjonowanie ruchu Sanctuary Movement. Następnie uczestnicy konferencji udali się obiad, który był okazją do kontynuacji nieformalnych dyskusji, nawiązania nowych kontaktów i integracji środowiska stypendystów.

Po obiedzie rozpoczęła się kolejna sesja konferencji prowadzona przez dr Magdalenę Żadkowską z Uniwersytetu Gdańskiego. Uczestniczyli w niej prof. UW dr hab. Bohdan Szklarski z Collegium Civitas oraz dr hab. Anna Horolets również reprezentująca Uniwersytet Warszawski oraz zespół badawczy, w skład którego weszli: dr hab. Adriana Mica (UW), dr Mikołaj Pawlak (UW) oraz dr Paweł Kubicki (SGH).

Prof. Bohdan Szklarski zaprezentował referat pt. „Imigranci w bieżącej polityce USA", w którym podkreślił, że dla przedstawicieli mniejszości etnicznych w USA wejście w politykę stanowi dowód awansu społecznego. Jako politycy (np. gubernatorzy, którzy mogą być urodzeni poza USA) imigranci mogą wpływać na bieg amerykańskiej polityki, a nawet historii. Prelegent przedstawił szeroko kontekst historyczny, omawiając cztery fale migracji do USA, a także stosunek społeczeństwa amerykańskiego do imigrantów w różnych okresach historii. Następnie omówił pokrótce regulacje ustawowe i wykazał, że występuje tendencja wzrostowa, jeśli chodzi o obecność członków mniejszości etnicznych w polityce (np. w Kongresie według jego wyliczeń przedstawiciele mniejszości stanowią ok. 22\% składu). Jego zdaniem jednak nie przekłada się to się na politykę, a w każdym razie, jak wielokrotnie podkreślał, nie w sposób przewidywalny. Wyliczył ponadto, że 72 gubernatorów w historii USA urodziło się poza granicami tego kraju, a spośród 12 tysięcy członków Kongresu (licząc od początku państwowości USA), 407 było urodzonych 
poza Stanami Zjednoczonymi. Co do ich skuteczności, nie był jednak przekonany i uznał, że dużo większy wpływ na politykę USA mieli tacy przedstawiciele mniejszości, jak Leon Czołgosz, który zabił prezydenta William McKinleya czy Sirhan Sirhan, który dokonał zamachu na Roberta Kennedy’ego. Tym kontrowersyjnym stwierdzeniem prof. Szklarski zakończył swoje wystąpienie.

$\mathrm{W}$ ramach ostatniej prezentacji dr hab. Anna Horoletz przedstawiła wyniki badań wspomnianego powyżej zespołu badawczego. Jej referat pt. „Czas przyszły, tryb przypuszczający: porównawcza analiza prasowych reprezentacji uchodźców w Europie Środkowej" dotyczył interdyscyplinarnego projektu, który miał na celu analizę dyskursu publicznego w sytuacji kryzysu. Prelegentka podkreśliła, że jego tematykę można również wpisać w zakres badań z tak zwanej socjologii niewiedzy. Swe wystąpienie rozpoczęła od zdefiniowania pojęcia niewiedzy, które jak podkreśliła, niekoniecznie musi być określeniem pejoratywnym. Niewiedza może bowiem motywować do zdobywania nowych informacji, umożliwia działanie i posiada moc twórczą. Niemniej może też powodować, że nie dostrzegamy lub lekceważymy elementy rzeczywistości, o których istnieniu nie wiemy. Ponadto, jak zaznaczyła, niewiedza może być nawet fabrykowana sztucznie, np. w celu zdobycia władzy. W takiej sytuacji osoby ubiegające się o władzę (lub jej zachowanie) świadomie lekceważą pewne fakty lub ukrywają je przed opinią publiczną. Następnie prelegentka wyjaśniła, że badania warszawskiego zespołu naukowców prowadzone były w Polsce, Rumunii i na Węgrzech. Przede wszystkim skupiono się w nich na analizie dokumentów i przekazów medialnych. Ponadto, w ramach badań terenowych przeprowadzono wywiady $\mathrm{z}$ aktorami związanymi z polityką uchodźczą $\mathrm{w}$ wymienionych krajach. Przeprowadzona analiza dyskursu wykazała, że przed 2015 rokiem $\mathrm{w}$ prasie dominowała ignorancja na temat uchodźców i polityki uchodźczej. W tym sensie niewiedza nie była fabrykowana, ale zwyczajnie brakowało podstawowych informacji, co mogło wynikać między innymi z faktu, że oprócz Węgier, pozostałe kraje nigdy nie spotkały się dużymi falami uchodźców. Choć obraz w mediach różnych proweniencji był nierówny, generalnym trendem był brak informacji i ton raczej neutralny. Zmiany w prasie zaobserwowano wraz ze zmianami na węgierskiej scenie medialnej. Wtedy to zaczęły pojawiać się negatywne konotacje terminu „uchodźca”. Występował on coraz częściej w zestawieniu z wyrazem „kryzys". Co prawda, pojawiały się też określenia i konteksty neutralne lub pozytywne (np. w Rumunii mówiono o możliwych korzyściach ekonomicznych z napływu ludności w długiej perspektywie, korzyściach demograficznych, możliwości wykorzystania wysokiego wykształcenia uchodźców, a na Węgrzech o korzyściach ekonomicznych, ale głównie dla Niemiec), niemniej zaczął dominować przekaz negatywny. Wśród negatywnych informacji zaczęto mówić, że uchodźców jest za dużo, będą sprowadzać całe rodziny, będą zagrożeniem dla bezpieczeństwa, muzułmanie nie będą się integrować, będą ciężarem dla ekonomii, nie znajdą pracy, mają niskie kwalifikacje, są fałszywymi uchodźcami, dlatego będą chcieli przywilejów 
socjalnych, ponadto przywiozą choroby i traumę wojenną, która uniemożliwi im stanie się dobrymi obywatelami. Prelegentka wyjaśniła, że w ramach dyskursywnego wymiaru niewiedzy analizuje się m.in. wyrażenia, które mają znaczenie tylko w określonym kontekście, a także czas i tryb, w którym formułowane są zdania. W swym wystąpieniu podkreśliła przede wszystkim fakt, iż większość wypowiedzi medialnych było formułowanych w czasie przyszłym, co może być oznaką poruszania się po obszarze niepewności albo niewiedzy. Jest to przewidywanie, jednak wyrażone $w$ taki sposób, by zamaskować niewiedzę. Z badań wynikało, że taki przekaz dominował zwłaszcza w prasie prawicowej. Z kolei przekazy na temat akcji humanitarnych w zasadzie nie występowały, a o budowaniu nowej polityki uchodźczej i humanitarnej mówiono jedynie w trybie przypuszczającym. Przekazy w czasie przyszłym były więc mocniejsze, choć w rzeczywistości również oparte na niewiedzy. Skłoniło to zespół do sformułowania wniosku, że niewiedza czy też ignorancja stały się podstawą tworzenia polityki publicznej.

Po wystąpieniu dr hab. Horoletz wywiązała się ciekawa dyskusja na temat powodów ignorancji oraz różnic między niewiedzą celową a niezamierzoną. Następnie władze muzeum zaprosiły uczestników konferencji do zwiedzania wystawy stałej. Towarzyszyli im przewodnicy, zapewniając dodatkowe informacje i przedstawiając ciekawostki, zarówno na temat historii migracji z ziem polskich, jak i procesu tworzenia ekspozycji i kolekcjonowania zbiorów. Część oficjalna konferencji zakończyła się Walnym Zebraniem Członków Klubu Stypendystów Fundacji Kościuszkowskiej, podczas którego do stowarzyszenia przyjęto nowych członków, ustalono plan działań na kolejne miesiące oraz debatowano nad miejscem kolejnej konferencji naukowej. Na zakończenie wszystkich uczestników spotkania zaproszono na uroczystą kolację. Był to czas na wymianę informacji na temat ciekawych spotkań naukowych, nawiązanie nowych kontaktów, a nawet podjęcie decyzji o wspólnych planach badawczych. 